\title{
POCZUCIE SENSU ŻYCIA A POSTAWA WOBEC S̃MIERCI
}

\section{WPROWADZENIE}

Problematyka sensu życia należy do centralnych zagadnień współczesnej psychologii, zwłaszcza jej humanistyczno-egzystencjalnego nurtu. Na gruncie tych kierunków psychologicznej refleksji o człowieku podejmuje się analizy sensu życia wychodząc z założenia, że właściwa grafikacja tej potrzeby jest zasadniczym źródłem motywacyjnym ludzkich zachowań ${ }^{1}$. Podkreślane przez V. E. Frankla znaczenie sensu życia jest dzisiaj rozumiane jako pytanie o najwyższą wartość, a odpowiedź na nie należy tak integralnie do istoty człowieka jak zdolność myślenia i tworzenia kultury ${ }^{2}$. Transcendując siebie poprzez uznawany system wartości człowiek nie powinien zatrzymywać się przed pytaniem o sens życia, ale szukać go w coraz pełniejszej formie. W przeciwnym bowiem wypadku dochodzi do wytworzenia się nerwicy noogennej, której osiowym objawem jest egzystencjalna pustka.

Człowiek posiadający wysokie poczucie sensu we własnym życiu w zasadniczy sposób określa swoje cele, jest otwarty na to, co niesie przyszłość. Wysaki sens daje mu poczucie pewności, zakorzenienie w życiu i szanse samoaktualizacji dzięki czemu życie staje się atrakcyjne. Przeciwne cechy charakteryzują osoby z niskim poczuciem sensu życia. Sensu życia nie można szukać poza życiem, ale w nim samym poprzez zrozumienie jego wymowy i odniesień do Nadsensu ${ }^{3}$. Potrzeba sensu życia jest 242.

1. Por. K. Obuchowski, Psychologia potrzeb ludzkich, Warszawa 1972, s. s. 77 .

2 Por. B. Grom, Auf der Suche nach dem Sinn des Lebens, Freiburg 1975,

${ }^{3} \mathrm{z}$ uwagi na problem niniejszego artykułu nie omawia sie szerzej zagadnienia Warszawa 1976; Psychoterapia dla każdego, Warszawa 1978; M. Ma zu ra, V. E. Frankla, Co mi daje sitę do życia, „Znak” 151 (1967) s. 40-49; Homo patiens, Warsizanwa 1976; Psychoterapia dla każdego, Warszarwa 1978; M. Ma zura, V. E. Frankl $i$ logoterapia, „Znak" 151 (1967) s. 32-39; K. P o p i els k i e go, Rola sensu $i$ wartości życia $w$ etiologii nerwicy noogennej $w$ ujęciu V. E. Frankla, ,Sprawozdania TN KUL" 19 (1972) s. 27-29; Rola idei wiodacej w procesie integracji osobowości „Summarium" 22 (1973) s. 253-258; V. E. Frankl. Analiza egzystencjalna $i$ logoterapia, „Zeszyty Naukowe KUL” 2 (1977) s. 63-78; D. Sleszyńskiego, Osobowość, zachowanie, sens życia, „Więź” 9 (1978) s. 26-31. 
ontogenetycznie pózniejsza od potrzeb biologicznych, ale równie silna i zazwyczaj jawi się w krańcowych i niekiedy dramatycznych sytuacjach, bowiem „człowiek chce żyć z sensem a nie za wszelką cenę" 4 .

Również w zasadniczych momentach życia pojawia się problem śmierci, jak to zaznacza m. in. V. E. Frankl. Podjął on w kontekście logoterapii analizę śmierci jako sytuacji granicznej. Wg niego śmierć nie jest wydzielonym fragmentem życia, lecz istotnym wymiarem istnienia. W bezwarunkowym nadawaniu sensu życiu musi być zawarty moment śmierci, gdyż tylko wobec śmierci życie jest sensownie spełnione (only in the face of death is it meaningfull). Po zetknięciu się ze śmiercią jako końcem absolutnym i granicą możliwości w człowieku odzywa się imperatyw jak najlepszego wykorzystania czasu życia ${ }^{5}$. W teorii Franklowskiej nie można mówić o śmierci bez odwoływania się do rozważań o czasie ${ }^{6}$. Człowiek bowiem żyje w czasie i czas żyje w człowieku. Końcowa śmierć jest tylko bardziej radykalną formą wygaśnięcia czasu. Za własną śmierć człowiek jest odpowiedzialny, gdyż jest odpowiedzialny za swój czas; dla logoterapii przeszłość jest prawdziwą przyszłością ${ }^{7}$. Umierający nie ma przyszłości, którą mógłby sobie jasno wyobrazić, ale istnieje dla niego konkretna przeszłość jako świadectwo życia. Tak więc w śmierci zbiega się przeszłość i przyszłość. Wprawdzie nie ma konkretnej przyszłości, ale w teraźniejszości umierania aktualizuje się przeszłość ${ }^{8}$. Smierć kończy okres stawania się. W śmierci człowiek ,,jest”, a ,,jest” w taki sposób jak „,był” w życiu.

Wydarzenie śmierci zachodzi nie tylko w terminalnej fazie ludzkiego życia, ale również w poszczególnych jego chwilach, gdyż suma śmierci momentów czasowych w człowieku konstytuuje egzystencję ludzką ${ }^{9}$. Franklowska koncepcja śmierci nie jest katastroficzna. Twórca III Szkoły Wiedeńskiej sądzi, że śmierć - jako naturalne zjawisko ludzkie - może odgrywać pozytywną rolę przez swój wyzywający charakter. By spełniała

${ }_{4}^{4}$ J. Różycka, Neurotyzm $w$ aspekcie psychologicznym na podstawie badań empirycznych, Wrocław 1979, s. 141.

5 V. E. Frankl, The Doctor and the Soul, New York 1967, s. 52.

${ }^{6}$ Por. R. P. Bulka, Death in Life-Talmudic and Logotherapeutic Affirmations, "Humanitas" 10 (1974) s. 37.

7 Tamże, s. 38.

${ }^{8}$ Widać tutaj duże podobieństwo do rekapitulacyjnej teorii umierania zaproponowanej przez Shneidmana (Aspects of the Dying Process, „Psychiatric Annals" $7-8,1977$, s. $391-397)$ z tym jednak, że reflekisja Franklkla pmzebiega na płaszczyźnie myślenia w kategoriach egzystencjalnych, zaś rozumowanie Shneidmana ma charakter biologiczno-psychiatryczny.

9 Jeżeli egzystencja człowieka w czasie jest jego czasowością (temporality) a egzystencja czasu w człowieku jedynością (singularity), to wobec tego myślenie o ludzkim bytowaniu bazuje na tych dwóch wymiarach. Również odpowiedzialność jednostki za własne życie musi być rozumiana w terminach czasowości i niepowtarzalności. Bezpowrotność przeszłego momentu (co świadczy o jego jedyności) oraz życia, które ma - globalnie je rozważając - cechy czasowości, wspólnie tworzą tło ludzkiej egzystencji. 
taką rolę musi być wintegrowana w psychikę człowieka, a zwłaszcza w pojmowanie życia, jego ocenę oraz widzenie siebie w relacjach interpersonalnych. Zarówno filozofowie jak i psychologowie są zdania, że zagadnienie przemijania i śmierci człowieka łączy się z sensem życia. I tak np. wg Schaffa śmierć jest głównym bodźcem do rozmyślania o sensie życia ${ }^{10}$. Maslow zaś uważa, że na podstawie stosunku człowieka do śmierci można orzekać o jego poczuciu sensu życia ${ }^{11}$.

Te teoretyczne ustalenia o powiązaniach postawy wobec śmierci z sensem życia zostały częściowo potwierdzone w trzech badaniach znanych dotychczas $w$ literaturze tanatologicznej ${ }^{12}$. W prezentowanych poniżej analizach uwzględnia się dane dotyczące korelacji poziomu sensu życia nie tylko z lękiem wobec śmierci i jej akceptacją (jak to było w dotychczasowych eksperymentach), ale także z innymi wymiarami i aspektami postawy wobec śmierci.

\section{BADANIA WEASNE}

Celem badań, które omawia prezentowany artykuł, jest udzielenie odpowiedzi na pytanie: czy istnieją związki między poziomem poczucia sensu życia i postawą wobec śmierci? Poszukiwania te obejmują tylko pewien wycinek omawianego problemu, bowiem badania dotyczą ściśle wiekowo określonej grupy respondentów, którzy zostali poddani badaniom dwoma standaryzowanymi testami. Przy pomocy ,,Skali sensu życia" ustalono poziom poczucia sensu życia i wyodrębniono dwie grupy psychometryczne, a na podstawie danych ,Inwentarza postawy wobec śmierci" określono postawę wobec śmierci tychże grup. Metody te poniżej pokrótce omówimy.

\section{Metody badań}

\section{A. „Skala sensu życia" (Purpose in Life Test - PLT)}

„Skala sensu życia" metrycznie ujmuje zjawisko egzystencjalnej frustracji, która może - zdaniem Frankla - wywoływać nerwicę noogenną. Twórcami tego tekstu są L. G. Croumbough i L. T. Macholik, a jego tłu-

10 Por. A. Schaff, Marksizm a egzystencjalizm, Warszawa 1961, s. 81.

11 A. M a slow, A Theory of Metamotivation: the Biological Rooting of the Value-Life, „Journal of Humanistic Psychology” 2 (1967) s. 93-127.

12 Są to badania grupy studentów (M. Bolt, Purpose in Life and Death Concern, „Journal of Genetic Psychology" 1, 1978, s. 159-160 oraz J. Durlak, Relationship between Individual Attitudes toward Life and Death, „Journal of Con'suliting and Clinical Psychollogy" 38, 1972, s. 463) i asób z domów stanców (E. Landau, B. M a o z, Creativity and Self-actualization in the Aging Personality, „American Journal of Psychotherapy” 1, 1978, s. 117-127). We wszystkich tych badaniach stwierdzono ujemną korelację między poziomem poczucia sensu życia i lękiem wobec śmierci. 
maczenia i adaptacji do naszych warunków dokonała prof. Z. Płużek w $1971 \mathrm{r}$.

Test PLT składa się z 3 części. Pierwsza z nich (A) zawiera 20 twierdzeń, z których każde jest oceniane na siedmiostopniowym kontinuum w postaci cyfr w porządku wzrastającym od 1 do 7 albo w porządku malejącym od 7 do 1 . Cyfra 1 oznacza minimalne, a 7 maksymalne nasilenie stanu określanego przez dane twierdzenie, cyfra 4 oznacza stan neutralny. Rzetelność skali, badana metodą korelacji twierdzeń parzystych z nieparzystymi, wynosi $r=0,81$.

Część druga (B) ma charakter projekcyjny i polega na uzupełnianiu 13 niedokończonych zdań. Część trzecia (C) stanowi propozycję dla badanego, by wypowiedział się w swobodny sposób na temat swoich ambicji, osiągnięć, marzeń i celów.

Pierwsza część pozwala w sposób ilościowy ująć intensywność poczucia sensu we własnym życiu. Wynik ten zyskuje się przez zsumowanie indywidualnych ocen każdego z 20 twierdzeń. Im wyższy wynik, tym wyższe zaspokojenie dążenia do znalezienia sensu życia, a im niższy wynik tym silniejsza frustracja egzystencjalna. W niniejszej pracy skalę PLT wykorzystano do wyodrębnienia dwóch skrajnych grup ze względu na intensywność odczuwania sensu we własnym życiu.

Spośród 250 osób w wieku 21-35 lat życia wyodrębniono te dwie zasadnicze grupy, z których każda liczyła po 50 respondentów ${ }^{13}$. Wynik globalny dla każdej z grup uzyskiwano przez dodanie ocen skalowych 20 twierdzeń. Wynosily one odpowiednio: dla grupy $\mathrm{z}$ wysokim poczuciem sensu życia średnia $\mathrm{M}_{\mathrm{ws}}=122,6$ (kobiety $-\mathrm{M}_{\mathrm{Wsk}}=123,2 ;$ mężczyźni $\mathrm{M}_{\mathrm{wsm}}=122,3$ ) a dla grupy $\mathrm{z}$ niskim poczuciem sensu we własnym życiu $\mathrm{M}_{\mathrm{NS}}=75,8$ (kobiety $-\mathrm{M}_{\mathrm{NSk}}=72,9 ;$ mężczyźni $-\mathrm{M}_{\mathrm{NSm}}=80,2$ ). Dwie grupy osób istotnie różniące się między sobą poziomem poczucia sensu życia stanowiły zmienną niezależną, natomiast zmienną zależną ujmowano przy pomocy „Inwentarza postawy wobec śmierci”.

\section{B. „Inwentarz postawy wobec śmierci” (IPS)}

Ze względu na to, że do tej pory nie ma w polskiej literaturze psychologicznej gotowej i adekwatnej metody badania postawy wobec śmierci, autor artykułu przygotował „Inwentarz postawy wobec śmierci”. Składa się on z trzech części: skali, kwestionariusza i uzupełniania niedokończonych zdań. Najlepiej matematycznie opracowana została skala. Zasto-

${ }^{13}$ Respondenci pochodzili z Krakowa, Wrocławia, Warszawy, Legnicy, Gdańska, Lublina, Torunia i Radomia. W skład każdej grupy wchodzili mężczyźni i kobiety $\mathrm{w}$ proporcjonalnym układzie. Wpływ innych zmiennych, jak: pochodzenie społeczne, stan cywilny i typ wykształcenia został wykluczony przez proporcjonalny rozkład w grupach psychometrycznych. Również wiek nie był istotną zmienną, gdyż średnia dla grupy $\mathrm{z}$ wysokim sensem $\dot{z} y c i a \mathrm{M}_{\mathrm{WS}}=26,2$, a dla grupy $\mathrm{z}$ niskim poczuciem sensu życia $\mathrm{M}_{\mathrm{NS}}=25,4$. 
sowano do tego tzw. taksonomię wrocławską w zmodyfikowanej formie ${ }^{14}$. Przy pomocy analiz czynnikowych, dostępnych w metodzie taksonomicznej, wyodrębniono 8 wymiarów postawy wobec śmierci. Są one następujące:

- Konieczność (Ko), czyli uświadamianie sobie nieuniknioności śmierci jako zjawiska całej przyrody,

- Centralność (Ce)=stopień zainteresowania problematyką śmierci, snucie o niej rozważań,

- Tajemniczość (Ta)=śmierć jawi się jako dręczące, głębokie i niewyjaśnione pytanie, najgłębsza tajemnica, której towarzyszy niepewność,

- Wartość (Wa)=śmierć jako możliwość zjednoczenia się z Bogiem, okazja do przeżycia czegoś ekscytującego. Śmierć posiada katarktyczny charakter, może doprowadzić do lepszego poznania siebie i uodpornić człowieka na trudne egzystencjalne przeżycia i problemy a także zmusić do korekt we własnym życiu.

14 Pośród różnych metod taksonomicznych w Polsce najbardziej jest znana tzw. taksonomia wrocławska. Opiera się ona na dendrycie, co pozwala klasyfikowane punkty leżące $\mathrm{w}$ przestrzeni wielowymiarowej tak odwzorować na płaszczyznę, aby suma odległości między rzutami tych punktów była najmniejsza (por. T. Grabiński, K. Z a ją c, Dynamiczna metoda badania struktur demograficznych, w: K. Z Z jąc, (red.), Metody statystyczne w badaniach społeczno-ekonomicznych, Warszawa 1975 , s. 19). Najogólniej mówiąc, taksonomia wrocławska służy do porządkowania zbioru ze względu na cechy jego elementów. Mając zbiór indywiduów możemy zapytać nie tylko o ich podobieństwo ze względu na reprezentowane cechy, lecz także o podobieństwo cech na tle owych indywiduów (K. Florek, J. Łukasiewicz, J. Perkal, I. Steinhaus, S. Zubrzycki, Taksonomia wrocławska, Poznań 1952, s. 17). W tym ostatnim przypadku zespół cech daje sie przedstawić jako zbiór punktów w przestrzeni wielowymiarowej, której osiami są indywidua. Daje to możliwość ustalenia przestrzennej odległości cech: mała odległość między cechami świadiczy o dużej korelaicji między nimi, a duża - o brakku mattematyicznego związku między zmiennymi. Clzęsto odlległaść mliędzy cechlami mierzy się poidając przzeicięitną różnicę cech obliczaną wg wzonu:

$$
D(A, B)=\frac{\left(a_{1}-b_{1}\right)+\left(a_{2}-b_{2}\right)+\ldots\left(a_{p}-b_{p}\right)}{p}
$$

gdzie: $D(A, B)$ jest odległością między obiektami (osobami) A i B, $a_{1}, a_{2}, \ldots$ a oraz $b_{1}, b_{2}, \ldots b_{p}$ to współrzędne tych punktów $w$ p wymiarowej przestrzeni (por. T. $\mathrm{Szulga}$, S. Gnot, Ilościowy i jakościowy aspekt cech $w$ numerycznych metodach taksonomicznych, „Postępy Mikrobiologii” 4, 1975, s. 14).

Operując pojęciem odliegłóści częściej w badaniach posługujemy się współczynnikkiem podobieństwa. Wispółiczynnilk ten olblicizony ze wzosu $\mathrm{P}(\mathrm{A}, \mathrm{B})=1-\mathrm{D}(\mathrm{A}, \mathrm{B})$ wskazuje, że im bardziej jalkieś cechy są do siiebie poidobne, tym odległość między nimi mniejsza. Takisonjomiczną ważność posziczególnych twier|dzeń skiali obliczono sitosując rachunek klonelaicy.jny wg następującego wzoru:

$$
r / X_{j}, x_{k}=\frac{\sum_{i} x_{i j} \cdot x_{i k}-\left(\frac{1}{N}\right)\left(\sum_{i} x_{i j}\right)\left(\sum_{i} x_{i k}\right)}{\left.\left.\left[\sum_{i} X_{i j}-\left(\frac{1}{N}\right) \sum_{i} X_{i j}\right)^{2}\right]^{1 / 2}\left[\sum_{i} X^{2}{ }_{i k}-\left(\frac{1}{N}\right)\left(\sum_{i} X_{i k}\right)^{2}\right)\right]^{1 / 2}}
$$

gdzie: $\mathrm{X}_{\mathrm{ij}}, \mathrm{X}_{\mathbf{2}}, \ldots \mathrm{X}_{\mathrm{nj}}$ to wartości cech dla poszczególnych osób $(=\mathrm{N})-$ por. T. Szulga, S. Gnot, jw., s. 21. 
- Groza $(\mathrm{Gr})=$ pod wpływem faktu a także problemu śmierci u ludzi powstaje lęk, trwoga, ból fizyczny,

— Tragiczność $(\operatorname{Tr})=$ śmierć jest percypowana jako wstrząsające i nieszczęśliwe wydarzenie, które wzbudza rozpacz,

- Destrukcyjność $(\mathrm{De})=$ śmierć niszczy możliwości rozwoju, poszukiwania sensu życia, demobilizuje aktywność ludzką,

- Absurdalność $(A b)=$ śmierć wyzwala uczucie beznadziejności, niedorzeczności, bezsensowności istnienia. W obliczu faktu przemijania wyzwala się żal o życie i do życia.

Rzetelność skali, obliczona jako współczynnik zgodności wewnętrznej, wynosi $r_{\mathrm{tt}}=0,74 \mathrm{i}$ jest wystarczająco wysoka, co świadczy o przydatności skonstruowanej skali do badań psychologicznych ${ }^{15}$. Oprócz tego wspólczynnika ustalono również współczynnik stałości, czyli tzw. stabilność bezwzględną dla poszczególnych wymiarów skali IPS. Zawiera się on w przedziale $\mathrm{r}=0,66-0,84$. Trafność treściową ustalono przy pomocy kompetentnych sędziów a czynnikową dzięki wspomnianej już analizie taksonomicznej.

Kwestionariusz wchodzący w skład ,Inwentarza postawy wobec śmierci" ma za zadanie ująć trzy aspekty śmierci, tj. śmierć człowieka obcego, bliskiego i własnej ${ }^{16}$.

W prezentacji materiału tworzącego niniejszy artykuł uwzględnia się jedynie dane ze skali i kwestionariusza a pomija treść niedokończonych zdań.

\section{Analiza statystyczno-psychologiczna}

Mimo wielu zastrzeżeń, jakie można żywić wobec danych statystycznych, pozostaje prawdą twierdzenie, że dane te pozwalają prześledzić ogólne tendencje w określonej grupie badanych. Tak również jest w przypadku danych testowych na temat śmierci.

W analizach psychologicznych uwzględni się najpierw zasadnicze różnice między grupami w zakresie 8 wymiarów postawy wobec śmierci a następnie odczucia i procesy myślowe związane z trzema aspektami tejże postawy.

Międzygrupowe porównania wymiarów postawy wobec śmierci przedstawia tabela 1.

15 M. Choynowski, Podstawy $i$ zastosowanie teorii rzetelności testów psychologicznych, w: J. Kozielecki, (red.), Problemy psychologii matematycznej, Warszawa 1971, s. 114-115.

16 Szczegółowy opis etapów konstruowania testu wraz z pełnym zestawem pytań znajduje się w moim artykule oddanym do druku w „Summarium” (1980). 
Tabela 1. Srednie wymiarów postawy wobec śmierci (M), odchylenia standardowe (SD) i istotność różnic między grupą z niskim poczuciem sensu życia (NS) i wysokim poczuciem sensu życia (WS)

\begin{tabular}{|c|c|c|c|c|c|c|}
\hline \multirow{2}{*}{$\begin{array}{l}\text { Wymiary } \\
\text { śmierci }\end{array}$} & \multicolumn{2}{|c|}{ NS } & \multicolumn{2}{|c|}{ WS } & \multirow[b]{2}{*}{$\mathrm{t}$} & \multirow[b]{2}{*}{$\mathrm{p}$} \\
\hline & M & SD & M & $\mathrm{SD}$ & & \\
\hline Konieczność (Ko) & 4,9 & 1,20 & 4,2 & 1,14 & 3,0801 & .0027 \\
\hline Centralność (Ce) & 3,2 & 1,23 & 2,6 & 1,15 & 2,2417 & .0272 \\
\hline Tajemniczość(Ta) & 5,1 & 1,23 & 4,6 & 1,44 & 2,1414 & .0347 \\
\hline Wartość (Wa) & 4,7 & 1,24 & 4,8 & 1,17 & $-0,6689$ & .9452 \\
\hline Groza (Gr) & 4,7 & 1,25 & 4,1 & 1,18 & 2,3139 & .0228 \\
\hline Tragiczność (Tr) & 4,8 & 1,38 & 4,4 & 1,38 & 1,4212 & .1584 \\
\hline Destrukcyjność (De) & 4,8 & 1,39 & 4,8 & 1,55 & 0,0000 & 1.0000 \\
\hline Absurdalność (Ab) & 4,1 & 1,50 & 3,8 & 1,61 & 0,7512 & .4544 \\
\hline
\end{tabular}

$(\mathrm{N}=50$ dla każdej z grup)

Jak wynika z powyższej tabeli, w 4 wymiarach postawy wobec śmierci istnieje statystycznie istotna różnica między grupą osób z wysokim sensem życia i osobami o niskim poczuciu sensu. Nie są to różnice wielkie i jakościowe, lecz ilościowe, wyrażające odmienną intensywność poszczególnych wymiarów śmierci u respondentów badanych grup. Osoby z wysokim poczuciem sensu życia nieco rzadziej dostrzegają konieczność śmierci i jej tajemniczość. Mniej się jej także boją, a ściślej mówiąc nie wiedzą (nie potrafią określić), czy się jej boją czy nie, gdyż na siedmiostopniowej skali uzyskują wynik 4,1 17. Między tymi dwoma grupami istnieje całkowita zgodność, gdy chodzi o widzenie destrukcyjnego charakteru śmierci i bardzo duże podobieństwo w widzeniu wartości śmierci jak równiė̇ jej absurdalnego charakteru. Najwyższym wymiarem, jaki osiągnięto w poszczególnym czynniku postawy wobec śmierci, jest Tajemniczość (por. wykres 1). Osoby z niskim poczuciem sensu życia podkreślają tajemniczość i problematyczność śmierci prawdopodobnie z tego powodu, że nie dają im one możliwości finalnego rozstrzygnięcia o sensie ludzkiej egzystencji.

W celu pogłębienia analizy struktury postawy wobec śmierci w każdej z grup psychometrycznych pożyteczny wydaje się zabieg prześledzenia interkorelacji, czyli wzajemnych powiązań wymiarów postawy wobec śmierci, jednej i drugiej grupy. Pozwala on poznać architektonikę postawy wobec śmierci. W poniższych tabelach uwidocznione są wzajemne powiązania 8 wymiarów postawy wobec śmierci u osób z niskim i wysokim poczuciem sensu życia.

$17 \mathrm{Na}$ siedmiostopniowej skali punkty 1 i 2 oznaczają negację, 6 i 7 afirmacje twierdzenia, a środkowy, tj. 4 wyraża brak własnego zdania $\mathrm{w}$ kwestii stawianej przez zadanie testu. 

Wykres 1. Poziom poczucia sensu życia a profil postawy
wobec simierci

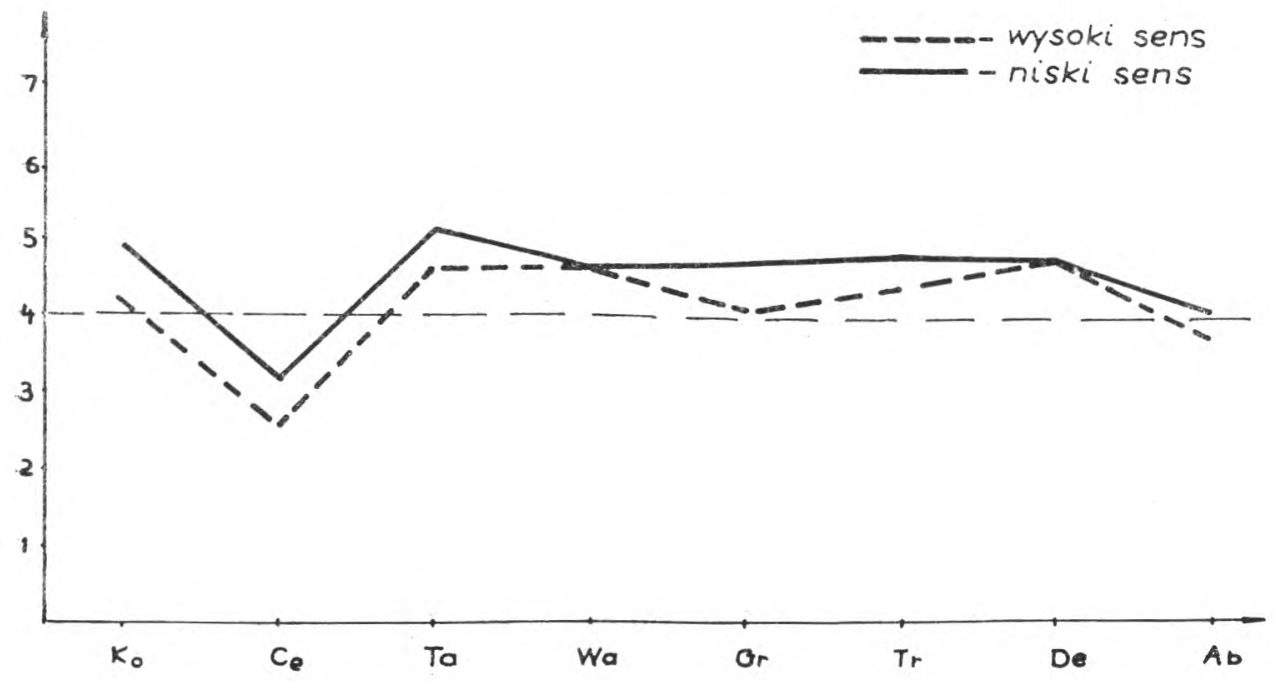

Tabela 2. Interkorlelacje wymiarów postawy wobec śmierci w grupie osób z niskim poczuciem sensu życia

\begin{tabular}{|l|lllllll|}
\hline \multicolumn{1}{|c|}{\begin{tabular}{l|l} 
Wymiary \\
śmierci
\end{tabular}} & Ko & Ce & Ta & Wa & Gr & Tr & De \\
\hline Konieczność (Ko) & & & & & & & \\
Centralność (Ce) & $.48^{* * * 18}$ & & & & & & \\
Tajemniczość (Ta) & .25 & .04 & & & & & \\
Wartośc (Wa) & $.36^{*}$ & $.45^{*}$ & .13 & & & & \\
Groza (Gr) & $.39^{* *}$ & $.35^{*}$ & $.43^{* *}$ & -.05 & & & \\
Tragiczność (Tr) & $.52^{* * *}$ & $.47^{* * *}$ & $.39^{* *}$ & .005 & $.58^{* * *}$ & & \\
Destrukcyjność (De) & $.32^{*}$ & .05 & $.40^{* *}$ & -.007 & $.40^{* *}$ & $.44^{* *}$ & \\
Absurdalność (Ab) & .20 & .03 & .24 & $-.33^{*}$ & $.40^{* *}$ & $.44^{* *}$ & $.47^{* * *}$ \\
& & & & & & & \\
\hline
\end{tabular}

$(\mathrm{N}=50, \mathrm{df}=48)$

Nieco inny układ wymiarów postawy osób wobec śmierci prezentuje grupa z wysokim poczuciem sensu życia. A oto tabela z macierzą korelacyjną.

${ }^{18}$ Symbol $\mathrm{xxx}$ oznacza istotność korelacji na poziomie $\mathrm{p}<.001, \mathrm{xx}-\mathrm{p}<.01$, $\mathrm{x}-\mathrm{p}<.05$. 
Tabela 3. Wzajemne powiązania wymiarów postawy wobec śmierci w grupie osób z wysokim poczuciem sensu życia

\begin{tabular}{|c|c|c|c|c|c|c|c|}
\hline $\begin{array}{l}\text { Wymiary } \\
\text { śmierci }\end{array}$ & Ko & $\mathrm{Ce}$ & $\mathrm{Ta}$ & Wa & $\mathrm{Gr}$ & $\operatorname{Tr}$ & $\mathrm{De}$ \\
\hline Konieczność (Ko) & & & & & & & \\
\hline Centralność (Ce) & $.53^{* * *}$ & & & & & & \\
\hline Tajemniczość (Ta) & .05 & -.18 & & & & & \\
\hline Wartość (Wa) & $.39^{* *}$ & $.036^{* *}$ & -.09 & & & & \\
\hline Groza (Gr) & $.43^{* *}$ & .14 & $.45^{* * *}$ & .15 & & & \\
\hline Tragiczność (Tr) & -.03 & -.26 & $.54^{* * *}$ & $-.32 *$ & $.46^{* * *}$ & & \\
\hline Destrukcyjność (De) & .03 & .007 & $.53^{* * *}$ & -.12 & $.48^{* * *}$ & $.68^{* * *}$ & \\
\hline Absurdalność (Ab) & -.11 & -.17 & $.49 * * *$ & $-.30^{*}$ & $.41 * *$ & $.63^{* * *}$ & $.67^{* * *}$ \\
\hline
\end{tabular}

$(\mathrm{N}=50, \mathrm{df}=48)$

Porównanie wewnętrznych struktur, charakterystycznych dla w/w grup, pozwala zauważyć niektóre znamienne cechy osób przynależących do dwóch grup psychometrycznych. I tak np. okazuje się, że tzw. centralność problematyki śmierci, czyli jej miejsce w siatce poznawczej jednostki, inaczej jest konstytuowana w grupie osób z niskim poczuciem sensu życia a inaczej u osób z wysokim poczuciem tegoż sensu: w pierwszej jest ona związana (dodatnia korelacja) z przeżywaniem śmierci w aspekcie jej tragiczności, wartości i konieczności - u drugiej natomiast dodatnią korelację widzimy jedynie z wymiarem wartości śmierci (jest to jednak słabsza korelacja niż w poprzedniej grupie), oraz - co jest szczególnie znamienne - ujemne powiązanie $z$ wymiarem tragiczności śmierci. Oznacza to m.in., że pojawienie się myśli o śmierci u osób z wysokim poczuciem sensu we własnym życiu powoduje złagodzenie jej tragiczności, lub lepiej - jest próbą oswojenia się z jej tragicznością. Można by się w tym wypadku domyślać pewnej racjonalizacji albo też próby przepracowania problematyki śmierci przez wysokie poczucie wartości życia, które niejako zaćmiewa jej wyzywający charakter.

Interesujące jest też powiązanie wymiaru tajemniczości z innymi czynnikami postawy wobec śmierci. Tajemniczość śmierci, tj. ujmowanie jej jako zjawisko mające w sobie swoistą nieodgadnioność, w grupie osób z wysokim sensem życia wiąże się, podobnie jak u osób z niskim sensem życia, z destrukcyjnością, lękiem i tragicznością, oraz - co jest charakterystyczne tylko dla tej grupy - z wymiarem absurdu (por. schemat 1). Na pozór mogłoby się wydawać, że powinno być odwrotnie, tzn. tajemniczość należałoby wiązać z absurdalnością w grupie osób z niskim poczuciem sensu życia. Jednakże pojawianie się tajemniczości śmierci wraz z jej absurdalnością wydaje się bardziej adekwatne właśnie w grupie osób z wysokim sensem życia z tego przede wszystkim powodu, że ktoś mający 
Schemat 1 . Jnterkorelacje Centralnosici, Tajemniczosici i Grozy Śmierci

NISKI SENS

WYSOKI SENS

Centralnosic
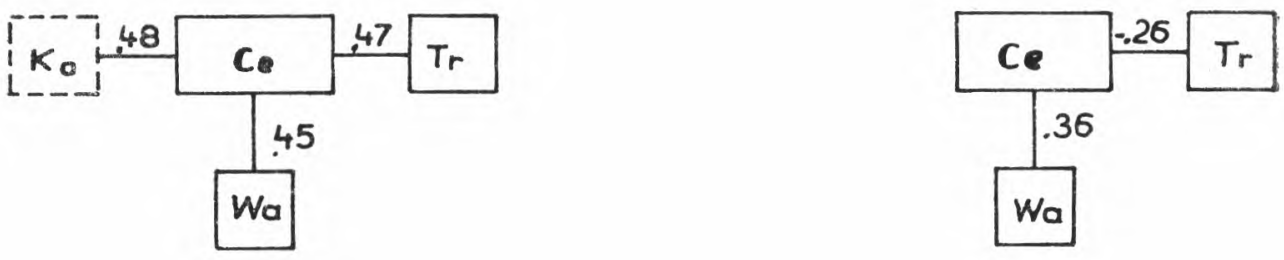

Tajemniczosí
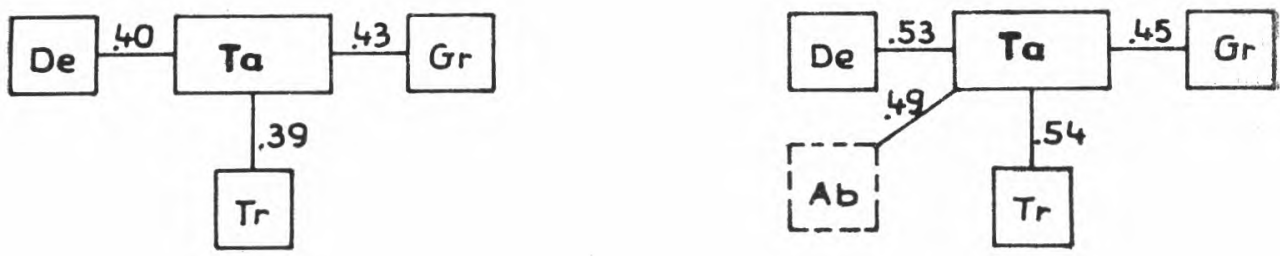

Groza
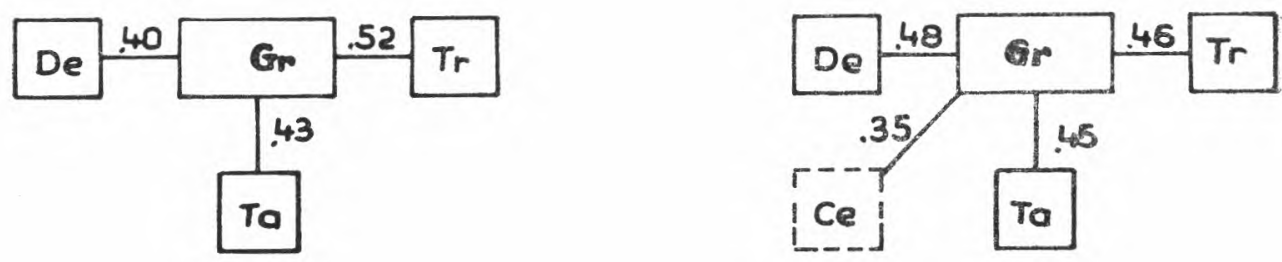
wyraźną filozofię życia nie lęka się widzenia śmierci także w aspekcie jej absurdalności.

Zwróćmy uwage jeszcze na lęk wobec śmierci i charakterystyczny brak jednego $\mathrm{z}$ wymiarów w grupie $\mathrm{z}$ wysokim sensem życia, który by $\mathrm{z}$ grozą śmierci wyraźnie korelował. Chodzi mianowicie o czynnik centralności, którego związek z grozą w grupie z niskim sensem życia jest wyraźny. Oznaczać to może, że u osób z niskim sensem życia już sama myśl o śmierci wywołuje lęk. Te empiryczne dane zdają się rzucać ciekawe światło na wielokrotnie w literaturze podejmowany problem: czy myślenie o śmierci wzbudza wobec niej lęk, czy też odwrotnie - lęk wobec śmierci zmusza do myślenia o niej, by ją niejako ułagodzić? W oparciu o dane empiryczne oraz możliwości interpretacyjne wyznaczone przez testy statystyczne możemy jedynie orzekać o współwystępowaniu lęku i myślenia o śmierci powstrzymując się od wyznaczania kierunku tejże zależności ${ }^{19}$.

Przy analizach powyższych danych pojawia się jeszcze jedno zagadnienie, które nie jest bez znaczenia $\mathrm{z}$ metodologicznego punktu widzenia: można bowiem pytać czy na różne konstelacje wymiarów postawy wobec śmierci w dwóch grupach psychometrycznych nie oddziałują np. odmienne wartości przez te grupy uważane za centralne. Gdyby tak było, całe poprzednie rozumowanie o wpływie poczucia sensu życia na konstelację wymiarów postawy wobec śmierci musiałoby ulec zawieszeniu, gdyż mielibyśmy wówczas do czynienia ze zmienną pośredniczącą. Bliższa analiza preferencji wartości 20 u osób z różnym poziomem sensu życia wykazała brak istotnych różnic w tym względzie między dwoma grupami $\left(\mathrm{Chi}^{2}=4,6013\right.$, df $\left.=5\right)$.

Zamykając psychometryczno-psychologiczną analizę związku poziomu poczucia sensu życia ze strukturą postawy wobec śmierci trzeba generalnie zauważyć, że nie ma radykalnych, czyli jakościowych, różnic w wymiarach postawy wobec śmierci między osobami z wysokim i niskim sensem życia. Są natomiast istotne różnice w skalowym poziomie poszczególnych wymiarów. Występują one w następujących 4 wymiarach postawy wobec śmierci: Centralności, Konieczności, Tajemniczości i Grozie. W zachowaniu przejawia się to tym, że osoby z wysokim sensem życia w wyższym stopniu niż osoby z grupy przeciwnej uznają konieczność śmierci,

${ }^{19}$ Kierunkową zależność można tłumaczyć przez odwołanie się do innej, pozastatystycznej, wiedzy o naturze tych zmiennych (lęku wobec śmierci i uświadamiania sobie jej problematyki). Autor artykulu stoi na stanowisku, że trudno jest jednoznacznie stwierdzić, która z tych zmiennych jest genetycznie pierwsza i raczej należy przyjąć ich dialektyczne oddziaływanie na siebie, bowiem obydwie są wyrazem zachowania się tego samego człowieka i znamieniem dynamiki jego osobowości.

20 Preferencję wartości ustalono przy pomocy Allporta „Zeszytu postaw wartościujących". 
nieco częściej o niej myślą, przypisują jej mniejszą tajemniczość i mniej się jej boją ${ }^{21}$. Obrazuje to graficznie wykres 1 .

Nie tylko na podstawie analizy, którą przeprowadził $\mathrm{K}$. Jaspers, ale również $\mathrm{w}$ oparciu o intuicję i potoczne doświadczenie można zakładać, że istnieją trzy różne aspekty postawy wobec śmierci. Mówiąc i myśląc o śmierci możemy bowiem mieć na uwadze śmierć jako zjawisko ogólne, spotykane przypadkowo (obraz TV, kondukt pogrzebowy, nekrolog). Charakterystyczna dla tej śmierci jest anonimowość wynikająca z obcości i nieznajomości zmarłego człowieka. Dwa następne rodzaje śmierci są zupełnie pozbawione tej anonimowości, gdyż łączą się one bądź to ze śmiercią bliskiej osoby, bądź też samego respondenta. Na tej podstawie w niniejszym artykule wyróżnione zostały trzy odrębne aspekty postawy wobec śmierci związane $\mathrm{z}$ różnymi szczegółowymi przedmiotami: 1) śmiercią obcego, nieznajomego człowieka ${ }^{22}, 2$ ) śmiercią bliskich, oraz 3 ) możliwością własnej śmierci.

Dane dotyczące w/w aspektów postawy wobec śmierci zabrano w oparciu o zadania drugiej części „Inwentarza postawy wobec śmierci”. W ich prezentacji za każdym razem najpierw przedstawiane będą rodzaje ,odczuć" związanych ze śmiercią, następnie częstotliwość myślenia o śmierci i w końcu - rodzaje pytań rodzących się pod wpływem spotkania śmierci oraz wpływ tego spotkania na styl życia.

\section{A. Uczuciowy kontekst myślenia o śmierci}

Tabela 4 zawiera procentowe zestawienia odczuć związanych z trzema różnymi aspektami ludzkiej śmierci: człowieka obcego, bliskiego oraz własnej. Z danych tych wynika, że - ogólnie biorąc - w myśleniu o śmierci człowieka obcego dominuje poczucie przemijania (47\% odpowiedzi). Między osobami z niskim i wysokim poczuciem sensu życia nie dostrzega się zasadniczych różnic statystycznych. Podobnie ma się rzecz z myśleniem o śmierci człowieka bliskiego, w którym u obydwu grup zaznacza się odczucie smutku (40\%). Jest zastanawiające, że odczucie strachu nie występuje u osób z wysokim poczuciem sensu życia, zarówno gdy myślą o śmierci jako zjawisku ogólnym jak i wtedy, kiedy przeżywają śmierć bliskich; natomiast w myśleniu o własnej śmierci ich strach i lęk jest rzadszym zjawiskiem niż u osób z niskim poczuciem sensu życia.

Innymi odczuciami wyraźnie wyeksponowanymi w myśleniu o śmierci bliskich jest ból (27\%) i rozpacz (21\%), przy czym w obydwu wypadkach

${ }^{21}$ Między kobietami a mężczyznami nie dostrzega się różnic w wymiarach postawy wobec śmierci poza jednym przypadkiem w grupie osób z niskim poczuciem sensu życia, kiedy kobiety widzą większe wartości śmierci niż mężczyźni $(t=2,0943$, $\mathrm{p}<.05)$.

${ }_{22} \mathrm{~W}$ dalszej części artykułu na określenie śmierci nieznajomego anonimowego człowieka będzie stosowane wyrażenie "śmierć obcego". 
Tabela 4. Procentowy rozkład odczuć związanych ze śmiercią człowieka obcego, bliskiego i własną $\mathrm{w}$ grupie $\mathrm{z}$ wysokim i niskim poczuciem sensu życia

\begin{tabular}{|c|c|c|c|c|c|c|c|c|c|}
\hline \multirow{2}{*}{$\begin{array}{l}\text { Zastanawianie się nad } \\
\text { śmiercią (obcego, blis- } \\
\text { kiego i własną) powodu- } \\
\text { je we mnie przede } \\
\text { wszystkim: }\end{array}$} & \multicolumn{3}{|c|}{$\begin{array}{c}\text { Śmierć człowieka } \\
\text { obcego }\end{array}$} & \multicolumn{3}{|c|}{ Smierć bliskiego } & \multicolumn{3}{|c|}{$\begin{array}{c}\text { Możliwość śmierci } \\
\text { własnej }\end{array}$} \\
\hline & NS & WS & $\begin{array}{l}\text { Ogó- } \\
\text { lem }\end{array}$ & NS & WS & $\begin{array}{l}\text { Ogó- } \\
\text { łem }\end{array}$ & NS & WS & $\begin{array}{l}\text { Ogó- } \\
\text { lem }\end{array}$ \\
\hline - niechęć do życia & 8,0 & 6,0 & 7,0 & 2,0 & 2,0 & 2,0 & 8,0 & - & 4,0 \\
\hline $\begin{array}{l}\text { - uczucie przemijania } \\
\text { - niepewność }\end{array}$ & 48,0 & 46,0 & 47,0 & 2,0 & 4,0 & 3,0 & 10,0 & 14,0 & 12,0 \\
\hline przyszłości & 4,0 & 10,0 & 7,0 & - & - & - & 10,0 & 2,0 & 6,0 \\
\hline - rozpacz & 2,0 & 2,0 & 2,0 & 26,0 & 16,0 & 21,0 & - & - & - \\
\hline - spokój & 4,0 & 8,0 & 6,0 & 6,0 & - & 3,0 & 10,0 & 8,0 & 9,0 \\
\hline - ból & 4,0 & 4,0 & 4,0 & 30,0 & 24,0 & 27,0 & - & - & - \\
\hline - żal za światem & 10,0 & 4,0 & 7,0 & 2,0 & 2,0 & 2,0 & 20,0 & 26,0 & 23,0 \\
\hline - nadzieję & 4,0 & 8,0 & 6,0 & - & 2,0 & 1,0 & 8,0 & 12,0 & 10,0 \\
\hline - smutek & 10,0 & 12,0 & 11,0 & 30,0 & 50,0 & 40,0 & 6,0 & 18,0 & 12,0 \\
\hline - strach i lęk & 6,0 & - & 3,0 & 2,0 & - & 1,0 & 28,0 & 20,0 & 24,0 \\
\hline
\end{tabular}

$(\mathrm{N}=100 \%)$

wyraźniej zaznaczają się one u osób z niskim sensem życia (różnica procentowa wynosi odpowiednio: w wypadku bólu 6\% a w rozpaczy - 10\%). Myśleniu o śmierci bliskiej osoby nie towarzyszy w ogóle uczucie niepewności. Jest to poniekąd niezrozumiałe, bowiem - jak wiadomo - odejście człowieka budzi określone refleksje, wszak nikt z ludzi nie jest samotną wyspą i pozostaje w wielorakich międzyosobowych powiązaniach. Cechą charakterystyczną owych relacji jest istnienie przynajmniej dwóch partnerów. Jeśli więc dochodzi do śmierci bliskiego człowieka-partnera interakcji, wówczas należałoby oczekiwać zachwiania się perspektywy przyszłości; śmierć wszelako stanowi koniec jakiegoś świata ludzkich przeżyć u obu stron. Być może, że odczucie niepewności przyszłości schodzi „,w cień" w porównaniu z tymi przeżyciami, które o wiele bardziej i bezpośrednio wiążą emocjonalnie aktywność człowieka, jak: smutek, ból, rozpacz. Prawie śladowo przejawia się wówczas nadzieja (1\%), żal za światem (2\%) i spokój (3\%). Nie zaznacza się wyraźnie niechęć do życia ani niepewność przyszłości, gdyż przeżywanie śmierci bliskiego człowieka jest jakby faktem samym w sobie a perspektywa własnego, młodego jeszcze życia stanowi inną rzeczywistość. Są one od siebie oddzielone wskutek działania mechanizmów obronnych, szczególnie wypierania i negacji.

Inaczej natomiast przebiega myślenie o własnej śmierci. Wtedy już respondent nie jest obojętny na świat - uczucie żalu za światem jest drugim $\mathrm{w}$ sensie popularności wyborów (23\%). Jest ono wyższe u osób 
z wyraźnym poczuciem sensu życia niż u osób z niskim poczuciem takiego sensu (różnica procentowa $=6 \%$ ). Wiodącym odczuciem $\mathrm{w}$ refleksji o własnej śmierci jest strach i lęk (24\%), ale jest wyższy (o 8\%) u osób $\mathrm{z}$ niskim poczuciem sensu życia (por. wykres 2).

Wykres 2. Odczucia zwiazane ze śmiercia cztowieka obcego/A/, bliskiego /B/, i wtasna/C/

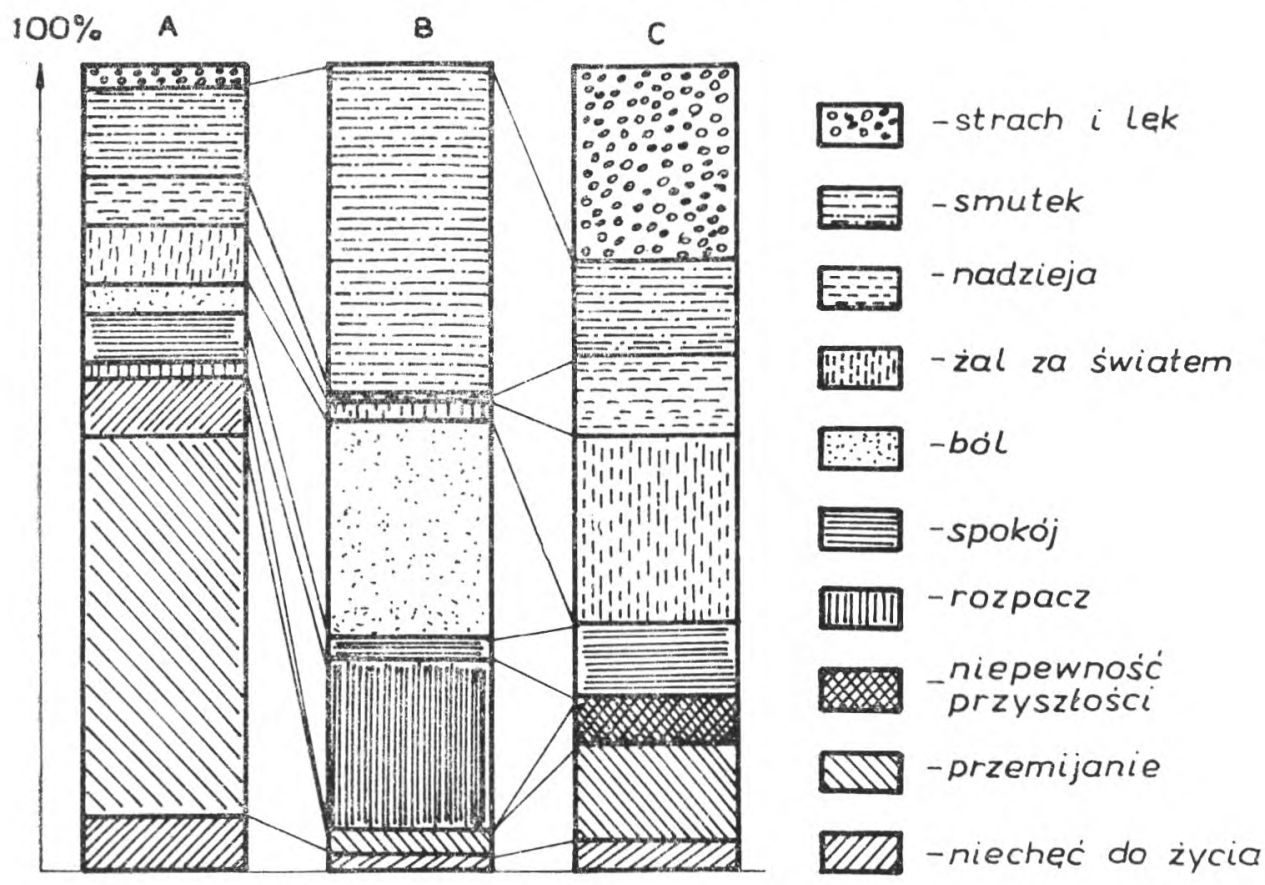

Charakterystycznym zjawiskiem w myśleniu o własnej śmierci jest brak odczucia bólu i rozpaczy oraz dość wyraźnie zaznaczony smutek (12\%) i uczucie przemijania (12\%).

Uwzględniając tylko ogólne tendencje w myśleniu o śmierci, a szczegółowiej - uczuciowy kontekst tego myślenia trzeba powiedzieć, że w miarę zmniejszania się dystansu do faktu bądź problemu śmierci wzrasta różnorodność odczuć z nią związanych. I tak, gdy myśli się o śmierci obcego, co zresztą niezbyt egzystencjalnie angażuje człowieka, pojawia się odczucie bardziej ,zintelektualizowane” i na wskroś filozoficzne (uczucie przenijania). Myślenie o przemijaniu jest przeżyciem bardziej intelektualnym niż emocjonalnym i dlatego zanika ono wówczas, kiedy konfrontacja ze śmiercią jest najbliższa z możliwych dla młodego człowieka, mianowicie w przeżywaniu śmierci bliskiej osoby. Wtedy pojawiają się odczucia „niewyrozumowane” (smutek, ból, rozpacz). Kiedy zaś dystans do 
własnej śmierci jest pośredni między jej anonimowością (śmierć obcego) a bezpośrednią faktycznością (śmierć bliskiego), obserwuje się i strach o sobie i refleksję o przemijaniu.

\section{B. Częstotliwość myślenia o śmierci}

Procentowy rozkład danych dotyczących częstotliwości myślenia o śmierci człowieka obcego, bliskiego i własnej przedstawia tabela 5 .

Wszystkie aspekty myślenia o śmierci w obydwu grupach rzadko tylko wyzwalają głębszą refleksję, przy czym najrzadziej myśli się o własnej śmierci, a nieco częściej o śmierci bliskiego człowieka. Wśród ludzi z niskim poczuciem sensu życia zdarzają się tacy, którzy twierdzą, że nigdy nie myśleli o żadnym z rodzajów śmierci. Taki rozkład wyników nie dziwi z tego powodu, że badanymi były osoby młode, dla których ważna jest aktywność życiowa i zaangażowanie w przyszłość. Zbyt częsta reflekssja o śmierci może powodować (przy niedojrzałej osobowości) nawet depresję i niesprawność psychiczną. Nie oznacza to jednak, że problematyka śmierci jest całkowicie psychicznie obca młodemu człowiekowi, bowiem prawie połowa respondentów bardzo często myśli o śmierci człowieka obcego $(45,7 \%)$, bliskiego $(49,7 \%)$ i własnej $(42 \%)$.

Można by suponować, że osoby z niskim poczuciem sensu życia częściej będą się zastanawiać nad śmiercią, aby ją zrozumieć i w ten sposób przynajmniej częściowo wzmocnić własne poczucie wartości życia. Jednakże prezentowane tutaj badania empiryczne nie upoważniają do takiego stwierdzenia, lecz do postawienia wniosku, że częstotliwość myślenia o śmierci nie ma istotnego związku z poziomem poczucia sensu własnego życia, lub inaczej - nadawanie sensu własnemu życiu nie jest skutkiem częstego myślenia o śmierci, ale jakości tegoż myślenia (por. tab. 5).

Tabela 5. Poczucie sensu życia a częstotliwość myślenia o śmierci obcego, bliskiego .i własnej (rozkład procentowy)

\begin{tabular}{|c|c|c|c|c|c|c|c|c|c|}
\hline \multirow{2}{*}{$\begin{array}{l}\text { O śmierci } \\
\text { myślę: }\end{array}$} & \multicolumn{3}{|c|}{$\begin{array}{c}\text { Smierć człowieka } \\
\text { obcego }\end{array}$} & \multicolumn{3}{|c|}{ Smierć bliskiego } & \multicolumn{3}{|c|}{$\begin{array}{c}\text { Możliwość śmierci } \\
\text { własnej }\end{array}$} \\
\hline & NS & WS & $\begin{array}{l}\text { Ogó- } \\
\text { lem }\end{array}$ & NS & WS & $\begin{array}{l}\text { Ogó- } \\
\text { lem }\end{array}$ & NS & WS & $\begin{array}{l}\text { Ogó- } \\
\text { łem }\end{array}$ \\
\hline $\begin{array}{c}\text { - bardzo } \\
\text { często }\end{array}$ & 6,0 & 6,7 & 6.4 & 10.0 & 133 & 117 & 80 & 100 & 90 \\
\hline - często & 32,0 & 46,7 & 39,3 & 36,0 & 40,0 & 38,0 & 36,0 & 30,0 & 33,0 \\
\hline - rzadko & 60,0 & 43,3 & 51,6 & 52,0 & 46,7 & 49,3 & 52,0 & 60,0 & 56,0 \\
\hline - nigdy & 2,0 & 3,3 & 2,7 & 2,0 & - & 1,0 & 4,0 & - & 2,0 \\
\hline
\end{tabular}

$(\mathrm{N}=100 \%)$ 
C. Myślenie o śmierci a rodzaj stawianych pytań

Myślenie o śmierci, dotyczące trzech jej aspektów, śmierci: obcego, bliskiego i własnej, prowokuje dwa główne pytania teoretyczne (poznawcze) i pragmatyczne (etyczne). W pierwszym przypadku chodzi o zagadnienie początku i celu życia, a w drugim o problem: co zrobić, by to życie, które się jeszcze ma, nie uległo zmarnowaniu?

Tabela 6 przedstawia procentowy rozkład wyboru odpowiedzi na każde $\mathrm{z}$ tych pytań.

Tabela 6. Myślenie o śmierci a rodzaj stawianych pytań przez grupy osób z zróżnicowanym poziomie poczucia sensu życia

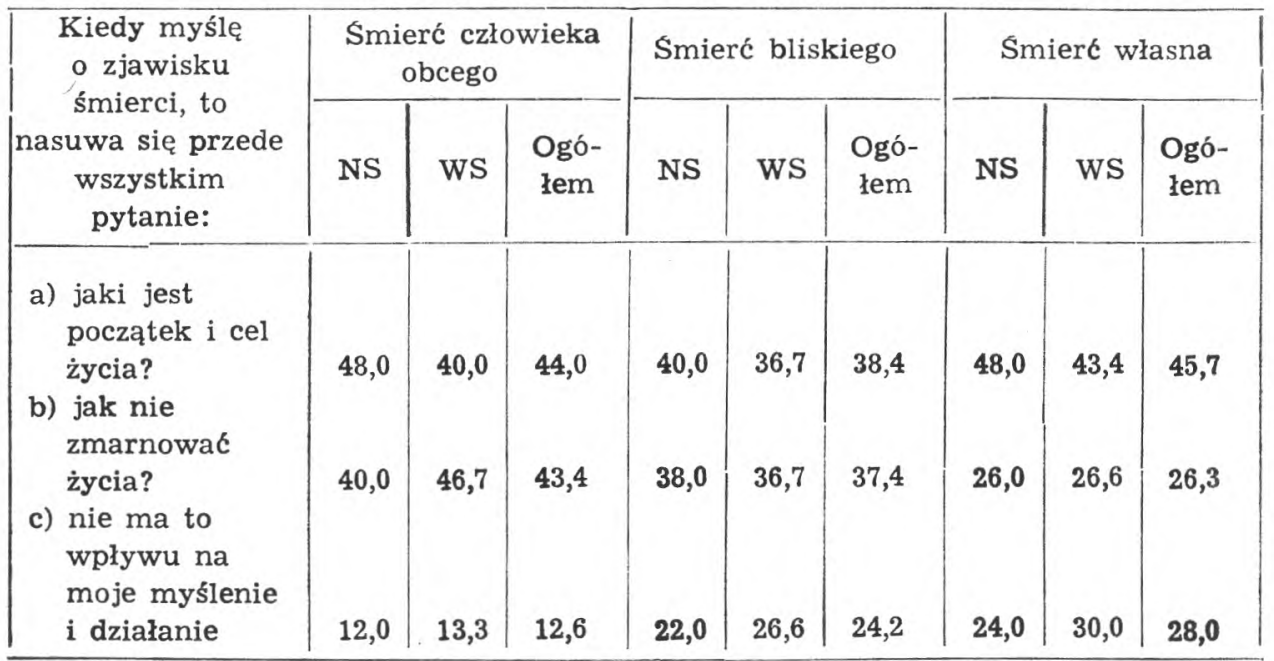

$(\mathrm{N}=100 \%)$

Najogólniejsza tendencja, przejawiająca się we wszystkich rodzajach śmierci (obcego, bliskiego i własnej), to podkreślanie pytania o początek i cel życia. Najwyraźniej zaznacza się to przy myśleniu o własnej śmierci $(45,7 \%)$. Również druga alternatywa (jak nie zmarnować życia?) jest silnie wyeksponowana w myśleniu o śmierci obcego i bliskiego, a najmniej w myśleniu o własnej śmierci. U osób z wysokim sensem życia spotkaniu się z problemem własnej śmierci towarzyszy względnie wysoka obojętność (np. częściej wybiera się odpowiedź: nie ma to wpływu na moje myślenie i działanie - 30\% niż pytanie: jak nie zmarnować życia $26,6 \%)$.

Podkreślanie problemu początku i celu życia w myśleniu o własnej śmierci próbuje się tłumaczyć zainteresowaniami filozoficznymi młodych ludzi, którzy nie mają jeszcze za sobą tzw. małej stabilizacji, po której następuje swoiste rozliczanie się z przeszłością i dokonywanie bilansu, 
by zdecydować, czy coś jest do naprawienia i co zostało zmarnowane jednym zdaniem: okres wczesnej dorosłości i średniego wieku to przede wszystkim czas zdobywania (także filozofii życiowej), a nie oceniania przeszłości.

D. Myślenie o śmierci a stosunek do życia

Dane procentowe wyboru różnych alternatyw pod wpływem myślenia o śmierci zestawia tabela 7.

Tabela 7. Refleksja o śmierci a stosunek do życia u ośb z niskim i wysokim poczuciem sensu własnej egzystencji

\begin{tabular}{|c|c|c|c|c|c|c|c|c|c|}
\hline \multirow{2}{*}{$\begin{array}{l}\text { Kiedy spotykam } \\
\text { się z faktem } \\
\text { śmierci, posta- } \\
\text { nawiam przede } \\
\text { wszystkim: }\end{array}$} & \multicolumn{3}{|c|}{$\begin{array}{c}\text { Smierć człowieka } \\
\text { obcego }\end{array}$} & \multicolumn{3}{|c|}{ Śmierć bliskiego } & \multicolumn{3}{|c|}{ Smierć własna } \\
\hline & NS & WS & $\begin{array}{l}\text { Ogó- } \\
\text { lem }\end{array}$ & NS & WS & $\begin{array}{l}\text { Ogó- } \\
\text { łem }\end{array}$ & NS & WS & $\begin{array}{l}\text { Ogó- } \\
\text { lem }\end{array}$ \\
\hline \multirow{3}{*}{$\begin{array}{l}\text { a) wykorzystać do } \\
\text { końca życie } \\
\text { b) poprawić się } \\
\text { c) nie czynię } \\
\text { żadnego } \\
\text { postanowienia }\end{array}$} & 8,0 & 10,0 & 9,0 & 10,0 & 16,7 & 13,3 & 22,0 & 16,7 & 19,3 \\
\hline & 42,0 & 40,0 & 41,0 & 36,0 & 40,0 & 38,0 & 50,0 & 50,0 & 50,0 \\
\hline & 50,0 & 50,0 & 50,0 & 54,0 & 43,3 & 48,7 & 28,0 & 33,3 & 30,7 \\
\hline
\end{tabular}

$(\mathrm{N}=100 \%)$

Z tabeli 7 wynika, że na człowieka najmniej działa refleksja o śmierci obcego i wtedy połowa respondentów nie czyni żądnego postanowienia, a reszta $\mathrm{w}$ znacznym procencie $(41 \%)$ pragnie się wówczas poprawić. Podobnie ma się rzecz z myśleniem o śmierci bliskiego. Natomiast w myśleniu o własnej śmierci sytuacja ulega dość radykalnej zmianie, mianowicie przeważa wówczas wybór alternatywy oznaczającej chęć poprawy siebie (50\%). Częściej też niż w przypadku dwóch poprzednich rodzajów śmierci pojawiają się pytania o to jak do końca wykorzystać życie $(19,3 \%)$. Między osobami z grupy o wysokim i niskim sensie nie ma istotnych statystycznych różnic.

Na podstawie powyższych danych może się nasunąć m.in. taki wniosek: młodym ludziom myślącym o własnej śmierci trudno jest pozostawać obojętnym na jej wyzywający charakter. Trzeba wtedy albo szukać sposobów wyeksploatowania życia albo skorygowania go. Tendencja ta jest charakterystyczna zarówno dla jednej jak i drugiej grupy psychometrycznej, czyli nie zależy od poziomu poczucia sensu własnej egzystencji. 


\section{ZAKONCZZENIE}

Poczucie sensu życia nie modyfikuje w zasadniczy sposób postawy wobec śmierci, ale wpływa jedynie na niektóre jej wymiary (Konieczność, Centrąlność, Tajemniczość, Groza). Podstawową zmienną, wyznaczającą widzenie śmierci przez badanych respondentów, jest nie tyle poziom sensu życia, lecz dystans do własnej śmierci (chodzi raczej o dystans psychologiczny, a nie czasowy).

Myślenie o śmierci nie jest zbyt częstym zjawiskiem w badanej próbce. Znaczna część respondentów pod wpływem śmierci niewiele zmienia styl własnego życia. Spotkanie ze śmiercią bardziej angażuje emocje człowieka a mniej procesy intelektualne, a zwłaszcza mechanizmy autokorekcji.

W następnych badaniach związku postawy wobec śmierci z poziomem poczucia sensu życia należy sięgnąć po inne jego rozumienie. Niezbyt liczne i wyraźne związki poziomu poczucia sensu życia z wymiarami i aspektami postawy wobec śmierci wynikają m.in. z tego, że operowano ogólnym pojęciem sensu życia bez jego szczegółowej precyzacji, a szczególnie odniesienia do wartości. W celu metodologicznej ścisłości stwierdzono jedynie, że rozkład wartości, ujętych przy pomocy typologii Sprangera, był proporcjonalny $\mathrm{w}$ dwóch omawianych grupach respondentów. Ale to wydaje się niewystarczające, bowiem każde poczucie sensu życia jest nasycone jakąś konkretną wartością. Uwzględnienie tej centralnej wartości, która konstytuuje sens życia jednostki, rzuci wiele nowego światła na interpretację związków poziomu poczucia sensu życia i postawy wobec śmierci. Zadanie to stanie się wykonalne dopiero wówczas, kiedy dostępna będzie inna metoda ujmowania sensu ludzkiej egzystencji.

\section{FEELING OF PURPOSE IN LIFE AND ATTITUDE TOWARD DEATH}

S u m m a r y

The article presents empirical research which was conducted among young people aged 21-35. Two methods were applied (1) L. G. Crumbaugh and L. T. Maholick's "Purpose in Life Test" and (2) "Inventory of Attitude toward Death" constructed by the author of this article. By using the first test with 250 respondents, two groups (each having 50 people) were distinguished. The first group contained those respondents with a low feeling of purpose in life $(M=75.5)$ whereas those with a high feeling of purpose in life were placed in the second group $(\mathrm{M}=122.6)$.

"Inventory of Attitude toward Death" consists of a Likert-type scale, questionnaire and incomplete sentence test. The scale touches 8 dimensions of attitude toward death (separated by applying the Wroclaw taxonomy): Necessity, Centrality, 
Misteriousness, Value, Anxiety, Tragicness, Destructiveness and Absurdity. The reliability of the scale $\mathrm{r}_{\mathrm{tt}}=0.74$.

Between persons with high and low feeling of purpose in life there are statistically significant differences in 4 dimensions: Necessity $(p<.01)$, Centrality $(p<.05)$, Misteriousness $(p<.05)$ and Fear of Death $(p<.05)$. They are not qualitative but quantitative differences. Persons with a low feeling of purpose in life experience more the necessity of death, its mysteriousness and anxiety.

Intercorrelational analyses within each group were likewise conducted and it was observed for instance that among people with a low feeling of purpose in life, a more intensive preoccupation with death clearly correlated with anxiety toward death $(p<.01)$.

Three aspects of the attitude toward death, i.e. toward the death of someone else, someone close and of oneself, can be derived by the second part of "The Inventory of Attitude toward Death". By thinking about death as a general phenomenon the feeling of change predominantes, by encountering the death of a close person - sadness, and the consideration of the possibility of one's own death accompanied by anxiety and grief in the face of departing from the world. The level of the feeling of life's purpose does not play any role in this area; a similar case is with the frequency of thinking about death because the giving of purpose to one's own life is not a result of frequent thinking about death but rather a result of the quality of that thinking. By thinking about one's own death both groups more often emphasize the wish to correct oneself $(50 \%)$ and pose the question: „How to make use of my life to the maximum?" (19.3\%).

A basic variable, which determines the attitude toward death of the tested population, is not level of the feeling of purpose in life but rather is the temporary and psychological distance to one's own death. Encountering death engages more the emotions and less the intellectual processes and particularly the self-regulatory mechanisms. 